\title{
Analyzing the Role of the Permanent and Temporary Shocks in Peru Using the Co-Movements Approach
}

\author{
Cesar R. Sobrino ${ }^{1}$ \\ ${ }^{1}$ Division of Business, Tourism, \& Entrepreneurship, UAGM - Gurabo Campus, Puerto Rico \\ Correspondence: Cesar R. Sobrino, Division of Business, Tourism, and Entrepreneurship, UAGM- Gurabo \\ Campus, PO BOX 3030, Gurabo, PR 00778, Puerto Rico. Tel: 001- 787-743-7979.
}

Received: September 25, 2021

Accepted: October 22, $2021 \quad$ Online Published: October 28, 2021

doi:10.5539/ijef.v13n11p115

URL: https://doi.org/10.5539/ijef.v13n11p115

\begin{abstract}
In this study, we use the co-movements approach to examine the role of permanent (common trend) and temporary (common cycle) shocks on per capita output, per capita consumption, and per capita investment in Peru, a small open commodity-based economy. Using quarterly data from 1993: Q1 to 2019: Q1, the effects of the temporary shocks are short-lived, and, on average, are a minor source of the variations of macro time series, over 10 quarters. This evidence suggests that the main source of per capita output and per capita consumption variations is the common trend shock which must be related to the 1990s reforms. Moreover, per capita output and per capita consumption are less responsive to unfavorable (favorable) common cycle shocks than per capita investment is. This outcome indicates that per capita investment has a much more volatile cycle than per capita private output and per capita consumption which is consistent with a previous empirical work
\end{abstract}

Keywords: common cycle, cointegration, forecasting

JEL Classification: C32, C53, E37.

\section{Introduction}

In the economic literature, frequently permanent shocks to output are interpreted as supply shocks and temporary shocks to output are interpreted as demand shocks. According to Blanchard and Quah (1989) and Gali (1999), the primary source of the permanent shocks is productivity, and the primary source of temporary shocks is the monetary policy. For small commodity-based economies, the terms of trade changes are another source of the temporary shocks. The terms of trade innovations are considered temporary because there is no evidence on terms of trade increasing living standards of the high-income commodity exporters, in other words, they are not productivity shocks. Specifically, Cashin and McDermott (2002) and Sobrino (2011) find that terms of trade shocks, allowed to be permanent to output growth, do not play any role on output growth variations (Note 1).

Peru, a small open commodity-based economy, is always exposed to favorable and unfavorable terms-of-trade shocks. In this sense, Dancourt, Mendoza, and Vilcapoma (1997), and Dancourt and Mendoza (2009) argue that Peru's recessions are largely associated with falls in terms of trade. In addition, Castillo, Montoro, and Tuesta (2006) indicate that, after the reforms in the 90s, there is a stronger nexus between the terms of trade and business cycles (Note 2). Likewise, Alimi and Aflouk (2017) found that that the volatility of terms of trade has a statistically significant and positive impact on the volatility of output growth (Note 3). However, Castillo et al. highlight the fact that since the 90 s reforms, the output volatility has fallen fourfold. According to Andrews \& Reeves (2009), small open countries with low inflation regimes, like Peru, show a low output volatility.

The facts mentioned above, low output volatility and business cycles tied to terms-of-trade innovations, invite the question about the role of temporary shocks (short-run) as well as permanent shocks (long-run) on macro time series in Peru overall because one of the goals of the 1990s reforms was to spur economic growth, avoiding high macroeconomic volatility, as occurred in the 1980s. In this sense, studies of the behavior of Peru's real GDP have focused on its trend-cycle decomposition to examine its upturns and downturns (Martinez \& Florian, 2019; Guillen \& Rodriguez, 2014; Terrones \& Calderon, 1993; and Seminario, 1992) and estimations of the GDP gap (Rodriguez, 2010a, 2010b; Seminario, Rodriguez, \& Zuloeta, 2007; Miller, 2003; and Cabredo \& Valdivia, 1999). Likewise, for Peru, among others countries, using a SVAR specification, Schmitt-Grohé and Uribe (2018) and Ben-Zeev, Pappa, and Vicondoa (2017) study the role of the terms of trade shocks on macro time series during 
business cycles, in other words, they carry out a short-term analysis (Note 4). Therefore, there is no evidence of the role of the temporary and the permanent shocks on macro time series variations for this country.

The goal of this study is to examine the role of permanent (common trend) and temporary (common cycle) shocks on Peru's per capita output, per capita consumption, and per capita investment using the co-movements approach. The co-movements approach involves finding short-and long-term relationships to set a trend-cycle decomposition and with it, find the sources of the variations of the macro time series. The main contribution of this study is to elucidate to role of the temporary and permanent shocks after the 90 reforms, as one of the goals of these reforms was to spur economic growth avoiding high macroeconomic volatility. In addition, this study provides empirical evidence on the lasting influence of the temporary shocks on per capita output, per capita consumption, and per capita investment. This empirical evidence is important for economic policymaking in Peru.

Using data from 1993:Q1 to 2019:Q1 (Note 5), it is found that the macro time series share a common trend and two common cycles. In addition, the outcomes indicate that the temporary shocks effects are short-lived, and, on average, are a minor source of macro time series variations over 10 quarters. This evidence suggests that the main source of per capita output and per capita consumption variations is the common trend shock which must be related to the reforms in the 1990s. Moreover, per capita output and per capita consumption are less responsive to unfavorable (favorable) common cycle shocks than per capita investment is. This outcome indicates that per capita investment has a much more volatile cycle than per capita private output and per capita consumption which is consistent with a previous empirical work. One explanation of the small role of the temporary shocks on the real output might be the low output volatility due to since 2002 , there has been adopted an inflation targeting regime.

The rest of the study is organized as follows: the second section discusses co-movements literature, the third section discusses the methodology and data, the fourth section presents the results, the fifth section discusses the outcomes, and the final section concludes.

\section{Co-Movements Literature}

Literature about co-movements is well known. The seminal work of Engle and Granger (1987) introduced the concept of cointegration. Likewise, Stock and Watson (1988) and Johansen (1991, 1988) examined the existence of a common stochastic trend among non-stationary time series (long-term co-movement). In addition, not conditional upon cointegration, Engle and Kozicki (1993) introduced the concept of serial correlation common feature (SCCF) to examine the common features among stationary times series (short-term co-movement). Conditional to cointegration, Vahid and Engle (1993) set a common feature test to examine synchronized common cycles among times series (Note 6).

In addition, common trend and common cycles are presented in theoretical models. One example is King, Plosser and Rebelo (1988) who extend Real Business Cycles models (Note 7). In this model, per capita private output, per capita consumption, and per capita investment, non-stationary time series, share a common trend which is productivity (permanent component). In turn, it is obtained two cointegrating relationships: 1) the subtraction of the per capita consumption and the per capita private output, and 2) the subtraction of the per capita private investment and the per capita private output (Note 8). Those linear combinations are stationary and known as the "great ratios" (Note 9). Likewise, applying first differences to the processes, the growth rates have two components a a white noise and a serial correlation which, according to Engle and Kozicki (1993) and Vahid and Engle (1993), implies the existence of a synchronized common cycle among the time series.

Using the co-movements approach, some literature analyzing the role of permanent and temporary shocks are Issler and Vahid (2001) analyzing macro time series in US and Gu and Lee (2007) examining macro time series in South Korea. The difference between them is that Issler and Vahid (2001) filter out fiscal spending effects, as the mentioned above theoretical model does, and $\mathrm{Gu}$ and Lee (2007) filter out external effects. This suggests that the first one does not consider fiscal shocks as part of temporary innovations, and the second one does not consider external shocks as part of the temporary innovations. Both studies find that the VECM including common trend and common cycles restrictions gains in relative efficiency with respect to those specifications when including long run restrictions.

For emerging economies, using Real Business Cycle models, there is mixed evidence about the role of permanent and temporary shocks on macroeconomic fluctuations. Aguiar and Gopinath (2007) find that the importance of permanent shocks accounts, on average, 84 percent of the macroeconomics variations. However, Akinci (2021), Drechsel and Tenreyro (2018) and Chang and Fernández (2013) find that temporary productivity shocks are more important in macroeconomic changes than trend shocks are. The inclusion of financial frictions, 
a stylized fact for emerging markets, alters Aguiar and Gopinath's outcome.

\section{Methodology}

A reduced $\operatorname{VAR}(p)$ with $n$ series $I(1)$ is converted into the following VECM:

$$
\Delta x_{t}=\tilde{\pi} \Psi+\pi x_{t-1}+\sum_{i=1}^{p-1} \pi_{i} \Delta x_{t-i}+\varepsilon_{t}
$$

where $x_{t}$ is the vector of time series; $\Psi$ is a vector of deterministic variables; $\tilde{\pi}$ is the matrix of coefficients of $\Psi ; \pi=-\left(I-\sum_{i=1}^{p} A_{i}\right) ; \pi_{i}=-\sum_{j=i+1}^{p} A_{j} ; A_{i}$ is the matrix of the VAR coefficients for all $i$ from 1 to $p ; \Delta$ is the first difference operator; and $\varepsilon$ is the matrix of disturbance terms $(\varepsilon \sim N(0, \Omega)) . \Omega$ is the variance-covariance matrix. According to Johansen (1991), if the rank of $\pi$ is $r$, where $r \epsilon] 0, n$ [, then $r$ linear combinations of $x_{t}$ that are $I(0)$ exist (Note 10). Also, $\pi=\alpha \beta^{\prime}$, where $\alpha$ and $\beta$ are the $(n \times r)$ matrices of adjustment coefficients and cointegrating vectors, respectively.

Once a long-term relationship is found among the series, the cointegrating vector(s) is(are) used to find Vahid and Engle (1993)'s statistic (VE) for the common cycle test. The test statistic is:

$$
c(p, s)=-(T-p-1) \sum_{i=1}^{s} \ln \left(1-\lambda_{i}^{2}\right)
$$

where $T$ is the number of observations, and, $\lambda_{i}^{2}$ 's $(\forall i=1, \ldots, s)$ are the smallest estimated squared canonical correlations between $\left\{\Delta x_{t}\right\}$ and $W(p) \equiv\left\{\beta^{\prime} x_{t-1}, \Delta x_{t-1}, \Delta x_{t-2}, \ldots, \Delta x_{t-p}\right\}$. Under the null hypothesis that there are at least $s(<n)$ cofeature vectors $\left(\tilde{\alpha}^{\prime}\right), c(p, s)$ has a $\chi^{2}$ distribution with $s(n p+r)-s(n-s)$ degrees of freedom. Finally, according to Vahid and Engle (1993), if the dimension of cointegraton space $(r)$ and the dimension of coefeature space $(s)$ is equal to the number of processes $(n)$, the long and short run vectors can be staked in a $(n \times n)$ matrix,

$$
A=\left[\begin{array}{l}
\tilde{\alpha}^{\prime} \\
\beta^{\prime}
\end{array}\right]
$$

where $A$ is a $n \times n$ matrix, full rank, and $\beta$ is the $(n \times r)$ matrix of cointegrating vectors. Using (3), it is possible to do a trend-cycle decomposition á la Beveridge and Nelson (1981). Then,

$$
x_{t}=A^{-1} A x_{t}=\tilde{\alpha}\left(\tilde{\alpha}^{\prime} \tilde{\alpha}\right)^{-1} \tilde{\alpha}^{\prime} x_{t}+\beta\left(\beta^{\prime} \beta\right)^{-1} \beta^{\prime} x_{t}
$$

where $x_{t}$ is the vector of time series, $\tilde{\alpha}\left(\tilde{\alpha}^{\prime} \tilde{\alpha}\right)^{-1} \tilde{\alpha}^{\prime} x_{t}$ is the permanent component (trend) and $\beta\left(\beta^{\prime} \beta\right)^{-1} \beta^{\prime} x_{t}$ is the temporary component (cycle).

Once the trend-cycle decomposition is set, we may find the role of the common trend (permanent) and common cycle (temporary) shocks on the macro time series. To do that, the common-trend shock of the variable is the common stochastic trend in first differences. Likewise, the common-cycle shocks are the residuals of (1) including long and short restrictions. Specifically, a Full Information Maximum Likelihood (FIML) is used on

$$
\Delta x_{t}=\left[\begin{array}{c}
-\widetilde{\alpha^{*}} \\
I_{n-s}
\end{array}\right]\left(\alpha^{*} X_{t-1}+\sum_{i=1}^{p-1} \pi_{i}^{*} \Delta x_{t-i}\right)+\varepsilon_{t}
$$

where $\widetilde{\alpha^{*}}$ are components of the cofeature vector when it is normalized, $\widetilde{\alpha}_{n \times s}=\left[\begin{array}{c}I_{s} \\ \widetilde{\alpha}^{*}(n-s) \times s\end{array}\right], X_{t-1}=\beta^{\prime} x_{t-1}$, and, $\alpha^{*}$ and $\pi_{i}^{*}$ are the $(n-s)$ bottom rows of $\alpha_{n-r}$ and $\pi_{i n \times n}$ of VECM, respectively. Likewise, for larger horizons, the common-trend shock is accumulated, and the common-cycle shocks is obtained by adding lags to (5). Finally, the common-trend and common-cycle shocks are orthogonalized to avoid correlation between them and execute the variance decomposition (Note 11).

\subsection{Data and Variables}

From 1993:Q1 to 2019:Q1, the Central Bank of Peru (Note 12) provides quarterly GDP, private consumption, gross fixed capital formation, fiscal spending, net exports, and population data. Macro time series are in 2007 constant nuevos soles and all series are seasonally adjusted. The theoretical model set three variables: per capita output, per capita consumption, and per capita investment. The per capita output is the GDP minus fiscal expenditure over population (as the theoretical model does), the per capita consumption is private consumption over population; and, per capita investment is gross fixed capital formation over population. The times series are converted in logs where $x_{t}=\left[\begin{array}{lll}y p e r_{t} & \text { cper }_{t} & \text { iper }_{t}\end{array}\right]^{\prime}$ and $n=3$. yper is the log of the per capita output, cper is the log of the per capita consumption, and, iper is the log of the per capita investment.

Figure 1 shows yper, cper, and, iper. At first glance, time series behave as I(1)s, sharing a common trend, and it seems that they share short term co-movements although, for consumption, downs are hard to identify. 


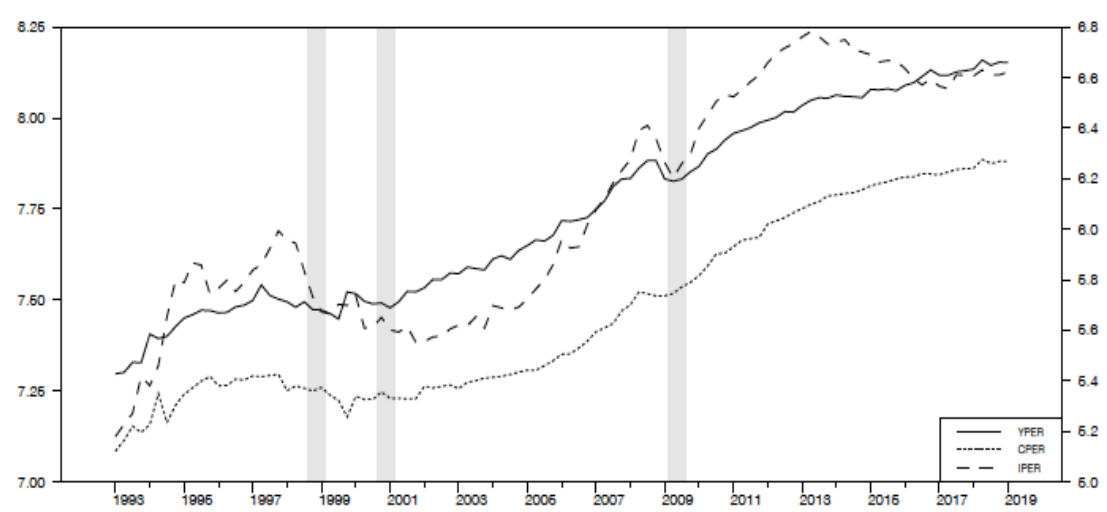

Figure 1. Log of output, consumption; and investment in Per- Capita Terms

Note. yper (fiscal spending accounted), and cper (left-hand side scale), and iper (right-hand side scale). 1998:Q4-1999:Q1; 2000:Q4-2001:Q1; and, 2009:Q2-2009:Q3 recessions in shadow bars.

In addition, Table 1 reports the unit root test. At 1,3, and 5 lags, yper, cper, and, iper are I(1)s.

Table 1. Elliott, Rothenberg, and Stock (1996)'s Unit Root Test

\begin{tabular}{|c|c|c|c|}
\hline & 1-lag & 3-lag & 5-lag \\
\hline \multicolumn{4}{|l|}{ At levels } \\
\hline yper & 2.347 & 1.631 & 1.626 \\
\hline cper & 2.989 & 1.525 & 1.850 \\
\hline iper & 0.437 & 0.233 & 0.520 \\
\hline \multicolumn{4}{|l|}{ In first differences } \\
\hline yper & $-7.025 * * *$ & $-5.213 * * *$ & $-3.831 * * *$ \\
\hline cper & $-4.370 * * *$ & $-1.639 *$ & -0.963 \\
\hline iper & $-4.877 * * *$ & $-3.573 * * *$ & $-2.625 * * *$ \\
\hline \multirow[t]{2}{*}{ Critical values } & $1 \%(* * *)$ & $5 \%(* *)$ & $10 \%(*)$ \\
\hline & -2.58 & -1.95 & -1.62 \\
\hline
\end{tabular}

Note. for all tests, a drift is included.

We set the optimal lag order of the VAR is 4 to capture one-year dynamics, so for VECM, the lag order is $p=3$ (Note 13).

\section{Results}

Table 2 reports the Johansen Trace test results. The null hypothesis that $r \leq 2$ cannot be rejected at 5\% significance, the null hypothesis that $r \leq 1$ is rejected at $5 \%$ significance, and $r=0$ is rejected at $5 \%$. So, we find two cointegrating relationships whose vectors are $(-1.02,1,0)^{\prime}$, and $(-1.56,0,1)^{\prime}$.

Table 2. Johansen Trace test

\begin{tabular}{cccc}
\hline$H_{0}$ & Eigenvalue & Statistic & Critical values at 5\% \\
\hline$r=0$ & 0.2025 & 39.72 & 29.51 \\
$r=1$ & 0.1274 & 15.93 & 15.2 \\
$r=2$ & 0.0157 & 1.66 & 3.96 \\
\hline
\end{tabular}

Note. A drift and trend are the deterministic terms.

The outcome supports the existence of one stochastic common trend (productivity) among the processes and the rank of the cointegrating space is $r=2$. In addition, the estimated normalized form for $\beta^{\prime}$ is the following matrix:

$$
\left[\begin{array}{lll}
-1.02 & 1 & 0 \\
-1.56 & 0 & 1
\end{array}\right]
$$

At the long run equilibrium, one percent increase in real GDP per capita (accounting for fiscal expenditures) will increase consumption per capita by almost 0.98 percent, and one percent increase in real GDP per capita will increase private investment per capita by 0.64 percent. In the long run, consumption per capita is more responsive 
to real output per capita than investment per capita is.

To test whether the the theoretical vectors $(-1,1,0)^{\prime}$, and $(-1,0,1)^{\prime}$, the "great ratios" may be imposed as restrictions on the cointegrating space on both settings, we use the following null hypothesis:

$$
\left[\begin{array}{lll}
-1 & 1 & 0 \\
-1 & 0 & 1
\end{array}\right]
$$

We cannot reject the null hypothesis because the p-value is $0.131\left(\chi^{2}(2)=4.064\right)$, respectively. This means that the restrictions are not binding, and we may use those ratios to test the short-run co-movements.

In order to test common cycles, we estimate the smallest squared canonical correlations between $\left\{\Delta y p e r_{t}\right.$, $\Delta$ cper $_{t}$, iper $\left._{t}\right\}$ and $W(3) \equiv\left\{\right.$ cper $_{t-1}-$ yper $_{t-1}$, iper $_{t-1}-$ yper $_{t-1}, \Delta y p e r_{t-1}, \Delta c p e r_{t-1}, \Delta i p e r_{t-1}$, $\Delta$ yper $_{t-2}, \Delta c p e r_{t-2}, \Delta$ iper $_{t-2}, \Delta$ yper $\left._{t-3}, \Delta c p e r_{t-3}, \Delta i p e r_{t-3}\right\}$. Table 3 shows the outcomes of this test. The null hypothesis that $s>0$ cannot be rejected at $1 \%$ significance, and the null hypothesis that $s>1$ and $s>2$ are rejected at $1 \%$ significance, so we may infer that $s$ is equal to one, resulting in two common cycles among the processes.

Table 3. Vahid and Engle' (1993) test

\begin{tabular}{lcccc}
\hline$H_{0}$ & $\lambda_{i}^{2}$ & VE statistic & DF & Critical values at $1 \%$ \\
\hline$s>2$ & 0.45 & 118.86 & 33 & 54.78 \\
$s>1$ & 0.33 & 58.76 & 20 & 37.57 \\
$s>0$ & 0.16 & 17.76 & 9 & 21.67 \\
\hline
\end{tabular}

Note. DF stands for degrees of freedom. The canonical correlations were calculated using the package CCA of R.

Then, given $n=r+s, A$ is the following one:

$$
\left[\begin{array}{ccc}
1 & 0.13 & -0.31 \\
-1 & 1 & 0 \\
-1 & 0 & 1
\end{array}\right]
$$

where the top row is the normalized cofeature column matrix $(\tilde{\alpha})$.

The trend-cycle decomposition coefficients $(A)$, reported in Table 4, are used to obtain the stochastic trends and common cycles (Note 14).

\begin{tabular}{|c|c|c|c|}
\hline & \multicolumn{3}{|c|}{ Long-and Short-Term Vectors } \\
\hline & yper & cper & iper \\
\hline Cofeature & 1 & 0.13 & -0.31 \\
\hline Cointegration 1 & -1 & 1 & 0 \\
\hline \multirow[t]{2}{*}{ Cointegration 2} & -1 & 0 & 1 \\
\hline & \multicolumn{3}{|c|}{ Trends } \\
\hline yper & 1.2127 & 0.1629 & -0.3757 \\
\hline cper & 1.2127 & 0.1629 & -0.3757 \\
\hline \multirow[t]{2}{*}{ iper } & 1.2127 & 0.1629 & -0.3757 \\
\hline & \multicolumn{3}{|c|}{ Cycles } \\
\hline yper & -0.2127 & -0.1629 & 0.3757 \\
\hline cper & -1.2127 & 0.8371 & 0.3757 \\
\hline iper & -1.2127 & -0.1629 & 1.3757 \\
\hline
\end{tabular}

Table 4. Trend-Cycle Decomposition

Table 5 shows the role of the temporary shocks on the processes (Note 15). In the per capita output variations, the role of the common cycle shock is less than 10 percent for all horizons but at the second quarter is around 11 percent. In addition, in per capita consumption variations, the role of the temporary shock is at the first quarter around 22 percent and continues decreasing (Note 16).

For per capita investment, the role of the temporary shocks is below 40 percent at the first quarter increasing up to the third quarter, above 70 percent. For almost one year, the temporary shocks play the biggest role in per capita investment fluctuations (Note 17), which contradicts the common wisdom that the productivity shocks are the main source of the investment changes. This result is consistent with Terrones and Calderon (1993) who find that 
investment is procyclical and has a much more volatile cycle than real GDP. For all variables, at the tenth quarter, the role of the temporary shocks is zero percent, which means that they are short-lived shocks. Instead, according to Issler and Vahid (2001)'s findings, the temporary shocks last for 20 quarters in the US which suggests that, in Peru, economic policy actions buffer positive and negative temporary shocks.

Table 5. The Role (\%) of Temporary Shocks

\begin{tabular}{cccccc}
\hline $\begin{array}{c}\text { Horizons } \\
\text { Quarters })\end{array}$ & $\begin{array}{c}\text { per capita } \\
\text { Output }\end{array}$ & $\begin{array}{c}\text { per capita } \\
\text { Consumption }\end{array}$ & $\begin{array}{c}\text { per capita } \\
\text { Investment }\end{array}$ & RVECM & UVECM \\
\hline & & & "Great Ratios" & \\
\hline 1 & 8.40 & 21.65 & 37.29 & $1.05678 \mathrm{E}-10$ & $8.16227 \mathrm{E}-05$ \\
2 & 11.26 & 17.83 & 61.02 & $6.22769 \mathrm{E}-11$ & $4.34561 \mathrm{E}-05$ \\
3 & 7.45 & 6.12 & 71.09 & $4.94106 \mathrm{E}-11$ & $3.16047 \mathrm{E}-05$ \\
4 & 2.73 & 2.08 & 44.27 & $2.8441 \mathrm{E}-11$ & $1.48993 \mathrm{E}-05$ \\
5 & 0.89 & 0.48 & 0.80 & $2.54002 \mathrm{E}-11$ & $1.2577 \mathrm{E}-05$ \\
10 & 0.00 & 0.00 & 0.00 & $1.30251 \mathrm{E}-11$ & $3.27801 \mathrm{E}-06$ \\
\hline & & & & $1.01409 \mathrm{E}-10$ & $8.16227 \mathrm{E}-05$ \\
\hline 1 & 8.13 & 21.53 & 36.12 & $6.2997 \mathrm{E}-11$ & $4.34561 \mathrm{E}-05$ \\
3 & 11.23 & 17.69 & 59.92 & $5.16076 \mathrm{E}-11$ & $3.16047 \mathrm{E}-05$ \\
4 & 7.42 & 6.06 & 68.55 & $2.99766 \mathrm{E}-11$ & $1.48993 \mathrm{E}-05$ \\
5 & 2.79 & 2.09 & 43.71 & $2.5843 \mathrm{E}-11$ & $1.2577 \mathrm{E}-05$ \\
10 & 0.91 & 0.47 & 0.82 & $1.16091 \mathrm{E}-11$ & $3.27801 \mathrm{E}-06$ \\
\hline
\end{tabular}

Note. $\mid$ MSFE $\mid$ is the determinant of the Mean Squared Forecasted Error (MSFE) matrix for the restricted VECM (RVECM) and the unrestricted VECM (UVECM). For individual equations, the Mean Squared Error (MSE) is similar across RVECM and UVECM.

Finally, using the original vectors $(-1.02,1,0)$ and $(-1.56,0,1)$ instead of the "great ratios", we find that common cycles and the common feature vector are quite similar. The forecast error variance decomposition, reported in Table 5 as well, shows no significant differences in the role common cycle shocks. Per capita output and per capita consumption are less responsive to adverse (favorable) common cycle shocks than per capita investment.

\section{Discussion}

The evidence indicates that the main source of per capita output and per capita consumption variations is the common trend shock which must be related to the reforms in the 1990s. Moreover, per capita output and per capita consumption are less responsive to unfavorable (favorable) common cycle shocks than per capita investment. One explanation of the small role of the temporary shocks on the real output might be the low output volatility due to the application of low inflation regimes as, since 2002, Peru has adopted an inflation targeting regime. According to Corbo and Schmidt-Hebbel and (2002), Schmidt-Hebbel and Werner (2002), and, for developing countries, Gonçalves and Salles (2008), the low output volatility is a stylized fact of the inflation targeting countries. For Perú, Castillo et al. indicate that since the 90 s reforms, the output volatility has fallen fourfold.

The outcome about the importance of the permanent shocks on macroeconomic fluctuations is consistent with Aguiar and Gopinath (2007) who, for emerging markets, one of them, Peru, find that the importance of permanent shocks accounts, on average, 84 percent of the macroeconomic variations. However, it is not consistent with Akinci (2021), Drechsel and Tenreyro (2018), and Chang and Fernández (2013) who find that temporary productivity shocks play a bigger role in macroeconomic variations than trend shocks do. The inclusion of financial frictions, a stylized fact for emerging markets, alters Aguiar and Gopinath's outcome. The degree of persistence of the productivity shocks invites the question about the role of permanent and temporary productivity shocks on macroeconomic fluctuations in Peru. Likewise, the result about the short-lasting temporary shocks is consistent with Schmitt-Grohe and Uribe (2018) and Ben-Zeev, Pappa, and Vicondoa (2017) who, for developing countries find that terms-of-trade shocks (interpreted as temporary ones) vanish about one year.

In addition, regarding consumption, according to Castillo et al., one stylized fact of the Peruvian economy is a low consumption volatility because of the presence of some consumption smoothing after the financial and trade openness. However, the presence of the temporary shocks on consumption variations might not mean the Permanent Income Hypothesis holds for Peru as Yanikkaya (2003) states (Note 18) and the findings of Sobrino 
(2013) about the rejection of Twin Deficits Hypothesis suggests.

Finally, the importance of the permanent shock suggests continuing the long-term policies. Some challenges are to increase the labor productivity, incentivize the creation of jobs in the formal economy, and increase the quality of public healthcare and public education levels. In addition, the improvement of infrastructure is necessary as well as the finishing of the reforms in the judicial and political systems.

\section{Conclusion}

The goal of this study is to examine the role of permanent (common trend) and temporary (common cycle) shocks on per capita output, per capita consumption, and per capita investment in Peru, a commodity-based economy, using the co-movements approach. We find that there is a common trend among the per capita output, per capita consumption, and per capita investment. Additionally, using the "great ratios", we find two common cycles among them these variables as well. With this information, and once the trend-cycle decompositon is addressed, we set the VECM including long-and short-term restrictions to obtain the forecast error variance decomposition.

Using quarterly data acquired after the reforms of the 1990s, the outcomes indicate that the temporary shocks are short-lived, and, on average, are a minor source of macro time series variations, over 10 quarters. The evidence suggests that the main source of per capita output and per capita consumption variations is the common trend shock, which must be related to the reforms in the 1990s. One explanation of the small role of the temporary shocks on the real output might be the low output volatility due to the application of low inflation regimes as, since 2002, Peru has adopted an inflation targeting regime. Moreover, per capita output and per capita consumption are less responsive to unfavorable (favorable) common cycle shocks than per capita investment. This outcome indicates that per capita investment has a much more volatile cycle than per capita private output and per capita consumption which is consistent with a previous empirical work.

The long-term implications of this study are related to the importance of the permanent shock on the per capita output and per capita consumption. The long-term policies still need to focus on to increase the labor productivity, incentivize the creation of jobs in the formal economy, and increase the quality of public healthcare and public education levels. In addition, the improvement of infrastructure is necessary as well as the finishing of the reforms in the judicial and political systems. All these policies are necessary conditions to increase the well-being of the Peruvians.

Finally, the short-term implications of this study are related to the short-term policymaking. For Peru, a small open commodity-based economy, the empirical evidence should increase the ability of response of the fiscal and monetary policy makers to adverse shocks. Further research should consider asymmetric cycles because, specifically, recessions are shorter than recoveries, and are sudden and violent. In addition, the degree of persistence of the productivity shocks should be included in future research. Also, the nominal shocks (as much as fiscal shocks), always considered temporary, should be included in a future analysis. Including nominal shocks, the presence of temporary shocks should increase.

\section{References}

Aguiar, M., \& Gopinath, G. (2007). Emerging Market Business Cycles: The Cycle is the Trend. Journal of Political Economy, 115(1), 69-102. https://doi.org/10.1086/511283

Akinci, Ö. (2021). Financial Frictions and Macro-Economic Fluctuations in Emerging Economies. Journal of Money, Credit and Banking, 53(6), 1267-1312. https://doi.org/10.1111/jmcb.12814

Alimi, N., \& Aflouk, N. (2017). Terms-of-trade Shocks and Macroeconomic Volatility in Developing Countries: Panel Smooth Transition Regression Models. The Journal of International Trade \& Economic Development, 26(5), 534-551. https://doi.org/10.1080/09638199.2016.1278029

Andrews, D., \& Rees, D. (2009). Macroeconomic Volatility and Terms of Trade Shocks. RDP 05, Economic Analysis Department, Reserve Bank of Australia. Retrieved from https://www.rba.gov.au/publications/rdp/2009/pdf/rdp2009-05.pdf

Ben-Zeev, N., Pappa, E., \& Vicondoa, A. (2017). Emerging Economies Business Cycles: The Role of the Terms of Trade Revisited. Journal of International Economics, 108, 386-376. https://doi.org/10.1016/j.jinteco.2017.07.008

Beveridge, S. B., \& Nelson, C. R. (1981). A New Approach to Decomposition of Economic Time Series into Permanent and Transitory Components with Particular Attention to Measurement of Business Cycle. Journal of Monetary Economics, 7, 151-174. https://doi.org/10.1016/0304-3932(81)90040-4

Brock, W. A., \& Mirman, L. J. (1972). Optimal Economic Growth and Uncertainty: The Discounted Case. 
Journal of Economic Theory, 4, 479-513. https://doi.org/10.2307/2525969

Cabredo, P., \& Valdivia, L. (1999). Estimacion del PBI Potencial: Peru 1950-1997. BCRP, Revista de Estudios Economicos, $5 . \quad$ Retrieved from https://www.bcrp.gob.pe/docs/Publicaciones/Documentos-de-Trabajo/1999/Documento-Trabajo-04-1999.pd $\mathrm{f}$

Cashin, P., \& McDermott, C. J. (2002). Terms of Trade Shocks and the Current Account: Evidence from Five Industrial Countries. Open Economies Review, 13, 219-235. https://doi.org/10.1023/A:1015292503142

Castillo, P., Montoro, C., \& Tuesta, V. (2006). Hechos Estilizados de la Economía Peruana. WP05, Banco Central de Reserva del Peru. Retrieved https://www.bcrp.gob.pe/docs/Publicaciones/Documentos-de-Trabajo/2006/Documento-Trabajo-05-2006.pd $\mathrm{f}$

Chang, R., \& Fernández, A. (2013). On the Sources of Aggregate Fluctuations in Emerging Economies. International Economic Review, 54(4), 1265-1293. https://doi.org/10.1111/iere.12036

Corbo, V., \& Schmidt-Hebbel, K. (2002). Inflation Targeting in Latin America. Documento de Trabajo IE-PUC No. 105.

Dancourt, O., \& Mendoza. W. (2009). Perú 2008-2009: del Auge a la Recesión. Choque Externo y Respuestas de Política Macroeconómica. In O. Dancourt, \& F. Jimenez (2009), Crisis Internacional: Impactos y Respuestas de Pol tica Economica en el Peru. PUCP.

Dancourt, O., Mendoza, W., \& Vilcapoma, L. (1997). Fluctuaciones Económicas y Shocks Externos, Peru 1950-1996. WP 135, Department of Economics, PUCP. Retrieved from http://files.pucp.edu.pe/departamento/economia/DDD135.pdf

Donaldson, J. B., \& Mehra, R. (1983). Stochastic Growth with Correlated Productivity Shocks. Journal of Economic Theory, 29, 282-312. https://doi.org/10.1016/0022-0531(83)90049-2

Drechsel, T., \& Tenreyro, S. (2018). Commodity Booms and Busts in Emerging Economies. Journal of International Economics, 112, 200-218. https://doi.org/10.1016/j.jinteco.2017.12.009

Elliott, G., Rothenberg, T., \& Stock, J. (1996). Efficient Tests for an Autoregressive Unit Root. Econometrica, 64, 813-836. https://doi.org/10.2307/2171846

Engle, R., \& Kozicki, S. (1993). Testing for Common Features. Journal of Business and Economic Statistics, 11, 369-396. https://doi.org/10.2307/1391623

Engle, R., \& Granger, C. (1987). Cointegration and Error Correction: Representation, Estimation and Testing. Econometrica, 55, 251-276. https://doi.org/10.2307/1913236

Gali, J. (1999). Technology, Employment and the Business Cycle: Do Technology Shocks Explain Aggregate Fluctuations? American Economic Review, 77(2), 111-117. https://doi.org/10.1257/aer.89.1.249

Gonçalves, C. E. S., \& Salles, J. M. (2008). Inflation Targeting in Emerging Economies: What do the Data Day?. Journal of Development Economics, 85(1-2), 312-318. https://doi.org/10.1016/j.jdeveco.2006.07.002

Gu, B., \& Lee, H. (2007). Common Trends, Common Cycles and Forecasting. The Journal of the Korean Economy, 8, 305-327. Retrieved from http://www.akes.or.kr/wp-content/uploads/2018/03/8-2-4.pdf

Guillen, A., \& Rodriguez, G. (2014). Trend-cycle Decomposition for Peruvian GDP: Application of an Alternative Method. Latin American Economic Review, 23(5). https://doi.org/10.1007/s40503-014-0005-3

Issler, J. V., \& Vahid, F. (2001). Common Cycles and the Importance of Transitory Shocks to Macroeconomic $\begin{array}{lllll}\text { Aggregates. Journal of } & \text { Monetary 479-475. }\end{array}$ https://doi.org/10.1016/S0304-3932(01)00052-6

Johansen, S. (1988). Statistical Analysis of Cointegration Vectors. Journal of Economic Dynamics and Control, 12, 231-54. https://doi.org/10.1016/0165-1889(88)90041-3

Johansen, S. (1991). Estimation and Hypothesis Testing of Cointegration Vectors in Gaussian Vector Autoregressive Models. Econometrica, 59, 1551-1580. https://doi.org/10.2307/2938278

King, R. G., Plosser, C. I., \& Rebelo, S. (1988). Production, Growth and Business Cycles: II. New Directions, Journal of Monetary Economics, 21, 309-341. https://doi.org/10.1016/0304-3932(88)90034-7

Klein, L. R., \& Kosobud, R. F. (1961). Some Econometrics of Growth: Great Ratios of Economics. Quarterly 
Journal of Economics, 75, 173-98. https://doi.org/10.2307/1884198

Kydland, F. E., \& Prescott, E. C. (1982). Time to Build and Aggregate Fluctuations. Econometrica, 50, 1345-1370. https://doi.org/10.2307/1913386

Long, J. B., \& Plosser, C. (1983). Real Business Cycles. Journal of Political Economy, 191(1), 39-69. https://doi.org/10.1086/261128

Martinez, M., \& Florian, D. (2019). Identificación y Fechado del Ciclo Económico en el Perú a partir de un Modelo de Componentes No Observables: 1980-2018. BCRP, Revista Moneda, 179, 26-30. Retrieved from https://www.bcrp.gob.pe/docs/Publicaciones/Revista-Moneda/moneda-179/moneda-179-05.pdf

Miller, S. (2003). Métodos Alternativos para la Estimación del PBI potencial: Una Aplicación para el Caso de Peru. BCRP, Revista de Estudios Economicos 10. Retrieved from https://www.bcrp.gob.pe/docs/Publicaciones/Revista-Estudios-Economicos/10/Estudios-Economicos-10-3.p df

Rodriguez, G. (2010a). Using a Forward-Looking Phillips Curve to Estimate the Output Gap in Peru. Review of Applied Economics, 10, 149-160. http://dx.doi.org/10.22004/ag.econ.143270

Rodriguez, G. (2010b). Estimating Output Gap, Core inflation, and the NAIRU for Peru, 1979-2007. Applied Econometrics and International Development, 10, 149-160.

Schleicher, C., \& Barillas, F. (2005). Common Trends and Common Cycles in Canadian Sectoral Output. Computing in Economics and Finance, 214.

Schmidt-Hebbel, K., \& Werner, A. (2002). Inflation Targeting in Brazil, Chile, and Mexico: Performance, Credibility, and the Exchange Rate. Central Bank of Chile, Working Paper No 171. https://doi.org/10.1353/eco.2002.0007

Schmitt-Grohe, S. \& Uribe, M. (2018). How Important are Terms-of-Trade Shocks? International Economic Review, 59, 85-111. https://doi.org/10.1111/iere.12263

Seminario B., Rodriguez, M., \& Zuloeta, J. (2007). Métodos Alternativos para la Estimación del PBI Potencial 1950-2007. UP, DD/07/20. Retrieved from https://repositorio.up.edu.pe/handle/11354/331?show=full

Seminario, B. (1992). Ciclos y Tendencias en el Peru 1950-1990. CIUP. Retrieved from https://repositorio.up.edu.pe/handle/11354/1619

Sobrino, C. (2011). Current Account, Productivity and Terms of Trade Shocks in Norway. Applied Economics Letters, 18, 1745-1750. https://doi.org/10.1080/13504851.2011.562154

Sobrino, C. (2013). Twin Deficits Hypothesis and Reverse Causality: A Short -Run Analysis of Peru. Journal of Economics, Finance, and Administrative Science, 34, 9-15. https://doi.org/10.1016/S2077-1886(13)70018-0

Solow, R. (1956). A Contribution to the Theory of Economic Growth. Quarterly Journal of Economics, 70 (1), 65-94. https://doi.org/10.2307/1884513

Stock, J., \& Watson, M. (1988). Testing for Common Trends. Journal of the American Statistical Association, 83, 1097-1107. https://doi.org/10.1080/01621459.1988.10478707

Terrones, M., \& Calderon, C. (1993). Ciclos Económicos en el Perú. WP 20, GRADE. https://doi.org/10.2139/ssrn.1732717

Vahid, F., \& Engle, R. F. (1993). Common Trends and Common Cycles. Journal of Applied Econometrics, 8, 341-360. Retrieved from https://www.jstor.org/stable/2285000

Vahid, F., \& Engle, R. F. (1997). Codependent Cycles. Journal of Econometrics, 80, 199-211. https://doi.org/10.1016/S0304-4076(97)00032-8

Yanikkaya, H. (2003). Household Consumption Expenditures in Peru: A Test for the Permanent Income Hypothesis. Journal of Economics and Administrative Sciences, 17, 65-73.

\section{Notes}

Note 1. The first one study analyzes Australia, Canada, and New Zealand and the second one analyzes Norway.

Note 2. From 1985 to 2019, on average primary exports represent $72 \%$ of total exports. Source: www.bcrp.gob.pe. 
Note 3. They use 44 commodity exporters, among them, Peru

Note 4 . They find that terms of trade shocks explain on average around 20 percent of the changes of per capita output, per capita consumption, and per capita investment.

Note 5. The reason of use this range is to avoid the non-linearity of the real GDP due to the 1990s structural changes. The non-linearity of the real GDP is addressed by Guillen and Rodriguez (2014).

Note 6. Vahid and Engle (1997) also analyze non-synchronized common features which are called "Codependent Cycles."

Note 7. Kyndland and Prescott (1982) and Long and Plosser (1983).

Note 8. Issler and Vahid (2001) and $\mathrm{Gu}$ and Lee (2007) discuss the algebraic solution.

Note 9. The Neoclassical Growth Model (Solow, 1956; Brock \& Mirman, 1972; and Donaldson \& Mehra, 1983) and Balance Growth model (Klein \& Kosobud, 1961) literatures imply that those ratios are stationary

Note 10. VAR is used in the first differences when $r=0$, and, if $r=n$, it means that $x_{t}$ is $I(0)$.

Note 11. Issler and Vahid (2001) and Schleicher and Barillas (2005), among others, explain the orthogonalization procedure.

Note 12. www.bcrp.gob.pe. Actually, Peruvian macro quarterly data starts at 1980:Q1 but, using a likelihood-ratio test for a three VAR setup, we found three structural breaks: 1990:Q3, 1991:Q1, and 1993:Q1.

Note 13. Using a Likelihood-ratio Test, for a maxlag $=4$, we compare VAR specifications including $1,2,3$, or 4 lags. Actually, we get 3 lags.

Note 14. For Peru, Guillén and Rodriguez (2014) run a trend-cycle decomposition of the real GDP using a non-observable components model to address the non-linearity of the real GDP, due to the 1990s structural changes, and asymmetric business cycles. The last issue means that contractions are shorter than expansions and are abrupt and violent.

Note 15. The complement represents the role of the permanent shocks.

Note 16. For a different period of analysis (1963-86), Terrones and Calderon (1993) find that consumption is procyclical and has less volatile cycle than real GDP does.

Note 17. This outcome is almost like that of Issler and Vahid (2001) who, for the US, find that, in the per capita investment fluctuations, the role of common cycles shocks is above $90 \%$ for one year

Note 18. He runs a cross sectional analysis for 1994.

\section{Copyrights}

Copyright for this article is retained by the author(s), with first publication rights granted to the journal.

This is an open-access article distributed under the terms and conditions of the Creative Commons Attribution license (http://creativecommons.org/licenses/by/4.0/). 